\title{
PENGARUH BUDAYA, DISIPLIN DAN KOORDINASI TERHADAP KINERJA KARYAWAN PT KERETA API INDONESIA (PERSERO) DAOP 1 JAKARTA
}

\author{
Oleh: \\ Rochmad Fadjar Darmanto \\ Sekolah Tinggi Ilmu Ekonomi IPWI Jakarta \\ rochmadfadjar@yahoo.co.id
}

\begin{abstract}
ABSTRAK
Tujuan penelitian ini adalah mengetahui pengaruh antara budaya kerja, disiplin kerja dan koordinasi terhadap kinerja karyawan PT Kereta Api Indonesia (Persero) Daop 1 Jakarta Pusat secara parsial dan simultan.

Metode penelitian yang digunakan dalam penelitian ini adalah analisis deskriptif kuantitatif, dengan ukuran sampel 40 orang responden yang diukur dengan uji validitas, reliabilitas, uji asumsi klasik, uji regresi ganda, uji koefisien determinasi dan uji hipotesis.

Hasil penelitian menunjukkan bahwa budaya kerja secara parsial berpengaruh positif dan signifikan terhadap kinerja, disiplin kerja secara parsial berpengaruh terhadap kinerja dan koordinasi secara parsial berpengaruh terhadap kinerja. Dari hasil uji koefisien determinasi diketahui nilai Adjusted $R$ Square menunjukkan nilai sebesar $87,5 \%$ sedangkan $12 \%$ sisanya dipengaruhi oleh variabel lain. Pada uji F hitung diketahui nilai F hitung sebesar 92,283 dengan nilai probabilitas signifikan sebesar 0,000<0,05 artinya bahwa budaya kerja, disiplin kerja dan koordinasi secara simultan (bersamasama) berpengaruh positif dan signifikan terhadap kinerja karyawan PT Kereta Api Indonesia (Persero) Daop 1 Jakarta. Dengan adanya peningkatan budaya kerja, disiplin kerja dan koordinasi maka kinerja karyawan juga akan mengalami peningkatan.
\end{abstract}

Kata kunci:

Budaya kerja, disiplin kerja, koordinasi dan kinerja

\section{PENDAHULUAN}

Dalam menyelenggarakan kegiatan kerja peranan karyawan pada PT Kereta Api Indonesia (Persero) Daop 1 Jakarta sangat penting. Karyawan merupakan aset utama organisasi dan mempunyai peran yang strategis dalam organisasi. Peningkaatan kinerja sumber daya manusia merupakan hal penting dalam mewujudkan organisasi yang ideal, karena sumber daya manusia lah yang menentukan dan memprediksi keberhasilan atau kegagalan suatu kebijakan, strategi, maupun langkahlangkah kegiatan yang akan dilaksanakan dalam suatu organisasi. Kinerja sumber daya manusia yang baik akan mempengaruhi perbaikan pelayanan kepada masyarakat, sehingga perlu diupayakan secara terus-menerus dan 
berkesinambungan dalam menghadapi tuntutan masyarakat. Kinerja merupakan gambaran tingkatt keberhasilan atau kegagalan pelaksanaan tugas pokok dan fungsi organisasi dalam mewujudkan sasaran, tujuan, visi dan misi organisasi. PT Kereta Api Indonesia (Persero) Daop 1 Jakarta memandang bahwa peningkatan kinerja sumber daya manusia atau karyawan dipengaruhi oleh beberapa faktor di antaranya budaya kerja, disiplin kerja dan koordinasi.

Budaya kerja merupakan bentuk keyakinan, nilai, cara yang bisa dipelajari untuk mengatasi dan hidup dalam organisasi, budaya kerja cenderung untuk diwujudkan oleh anggota organisasi. Robbins (2007:525) menjelaskan bahwa budaya kerja itu merupakan suatu system nilai yang dipegang dan dilakukan oleh anggota organisasi. Budaya organisasi banyak dipengaruhi cara karyawan bertingkah lagu, cara menggambarkan pekerjaannya, dan cara memandang masa depan dengan wawasan yang luas ditentukan oleh norma, nilai dan kepercayaannya. Setiap karyawan memiliki budaya kerja yang berbeda, disebabkan mereka memiliki latar belakang budaya yang berbeda. Semua perbedaan itu akan dilebur menjadi satu dalam sebuah budaya, yaitu budaya kerja. Membentuk budaya kerja yang akan menentukan keberhasilan suatu organisasi, apapun bentuk dan tujuan organisasi tersebut. Budaya kerja juga dianggap mempengaruhi hubungan dan suasana kerja kea rah yang lebih baik, serta mampu mempengaruhi hasil kerja dan kepuasan yang lebih baik.

Faktor lain yang mempengaruhi peningkatan kinerja adalah disiplin kerja yang dimiliki oleh para karyawan baik bentuk disiplin diri maupun disiplin kelompok. Untuk mencapai tujuan suatu organisasi, diperlukan adanya para pegawai yang memiliki disiplin yang fungsi kedisiplinan sebagai salah satu unsur penting dalam suatu organisasi. Kedisiplinan sangat penting dalam peningkatan kinerja seseorang, sebab dengan disiplin maka semua tugas akan dapat selesai dengan baik dan tepat waktu. Menurut Fathoni (2006: 172) Kedisiplinan adalah kesadaran dan kesediaan seseorang menaati semua peraturan perusahaan dan norma-norma sosial yang berlaku. Jadi kedisiplinan dapat diartikan bilamana pegawai datang dan pulang tepat waktunya, mengerjakan semua pekerjaannya dengan baik, mematuhi semua peraturan perusahaan dan normanorma sosial yang berlaku. Kedisiplinan harus ditegakkan dalam suatu organisasi karena tanpa dukungan disiplin pegawai yang baik, maka sulit bagi organisasi untuk mewujudkan tujuannya. Jadi kedisiplinan adalah kunci keberhasilan suatu organisasi mencapai tujuan.

Selain faktor kedisiplinan yang tidak kalah penting lagi adalah factor koordinasi adalah kegiatan mengarahkan, mengintegrasikan, dan mengkoordinasikan unsur-unsur manajemen dan pekerjaan-pekerjaan para bawahan dalam mencapai tujuan organisasi" sedangkan Handoko (2003:195) mengatakan bahwa koordinasi adalah proses pengintegrasian tujuan-tujuan dan kegiatan-kegiatan pada satuan-satuan yang terpisah (departemen-departemen atau bidang-bidang fungsional) pada suatu organisasi untuk mencapai tujuan secara efisien dan efektif dan koordinasi adalah mengimbangi dan menggerakkan tim dengan memberikan lokasi kegiatan pekerjaan yang cocok kepada masingmasing dan menjaga agar kegiatan itu dilaksanakan dengan keselarasan yang semestinya di antara para anggota itu sendiri. 


\section{TUJUAN PENELITIAN}

Tujuan dari penelitian ini adalah:

a. Untuk mengetahui pengaruh budaya kerja terhadap kinerja karyawan PT Kereta Api Indonesia (Persero) Daop 1 Jakarta.

b. Untuk mengetahui pengaruh disiplin kerja terhadap kinerja karyawan PT Kereta Api Indonesia (Persero) Daop 1 Jakarta.

c. Untuk mengetahui pengaruh koordinasi terhadap kinerja karyawan PT Kereta Api Indonesia (Persero) Daop 1 Jakarta.

d. Untuk mengetahui pengaruh budaya kerja, disiplin kerja dan koordinasi secara simultan terhadap kinerja karyawan PT Kereta Api Indonesia (Persero) Daop 1 Jakarta.

\section{TELAAH LITERATUR DAN PENGEMBANGAN HIPOTESIS \\ Budaya Kerja}

Budaya Kerja menurut Gering, Supriyadi dan Triguna (2011: 7), adalah suatu falsafah yang didasari oleh pandangan hidup sebagai nilai-nilai yang menjadi sifat, kebiasaan, dan kekuatan pendorong, membudaya dalam kehidupan suatu kelompok masyarakat atau organisasi yang tercermin dari sikap menjadi perilaku, kepercayaan, cita-cita, pendapat dan tindakan yang terwujud sebagai kerja atau bekerja.

Hadari Nawawi (2013) menyebutkan bahwa budaya kerja adalah kebiasaan yang dilakukan berulang-ulang oleh pegawai dalam suatu organisasi, pelanggaran terhadap kebiasaan ini memang tidak ada sanksi tegas, namun dari pelaku organisasi secara moral telah menyepakati bahwa kebiasaan tersebut merupakan kebiasaan yang harus ditaati dalam rangka pelaksanaan pekerjaan untuk mencapai tujuan.
Menurut Taliziduhu Ndraha (2005), budaya kerja merupakan sekelompok pikiran dasar atau program mental yang dapat dimanfaatkan untuk meningkatkan efisiensi kerja dan kerjasama manusia yang dimiliki oleh suatu golongan masyarakat. Budaya kerja berbeda antara organisasi satu dengan yang lainnya, hal itu dikarenakan landasan dan sikap perilaku yang dicerminkan oleh setiap orang dalam organisasi berbeda.

Menurut Taliziduhu Ndraha (2005:209) budaya kerja mempunyai unsurunsur, yaitu a) Anggapan dasar tentang kerja, sikap terhadap pekerjaan, lingkungan kerja dan alat kerja, dan etos kerja. Suatu pendirian atau anggapan dasar terbentuk melalui konstruksi pemikiran silogistik. Premisnya adalah pengalaman hidup. Sedangkan manusia menunjukkan berbagai sikap terhadap pekerjaan, yaitu kecenderungan antara menerima sepenuhnya atau menolak. Sikap dalam bekerja, lahir perilaku bagaimana seseorang dalam bekerja. Manusia membangun lingkungan kejra yang nyaman dan menggunakan alat (teknologi) agar dapat bekerja efektif, efisien dan produktif. Etos kerja merupakan watak atau semangat fundamental budaya, berbagai ungkapan yang menunjukkan kepercayaan, kebiasaan, atau perilaku suatu kelompok masyarakat.

\section{Disiplin Kerja}

T. Hani Handoko (2010) menyebutkan bahwa disiplin adalah kegiatan manajemen untuk menjalankan standarstandar organisasional. Disiplin Kerja merupakan sikap mental yang tercermin dalam perbuatan atau tingkah laku individu, kelompok, atau masyarakat berupa ketaatan terhadap peraturanperaturan atau ketentuan yang ditetapkan untuk tujuan tertentu. 
Disiplin kerja menurut Rivai (2004:444) adalah suatu alat yang digunakan manajer untuk berkomunikasi dengan karyawan agar mereka bersedia untuk mengubah suatu perilaku serta sebagai suatu upaya untuk menningkatkan kesadaran dan kesediaan seseorang mentaati semua peraturan perusahaan dan norma-norma sosial yang berlaku.

Dalam Malayu Hasibuan (2012:193) disebutkan bahwa disiplin adalah kesadaran dan kesediaan seseorang menaati semua peraturan perusahaan dan norma-norma social yang berlaku. Disiplin kerja karyawan harus ditegakkan dalam suatu organisasi perusahaan. Tanpa dukungan disiplin kerja dari karyawan, sulit bagi perusahaan untuk mencapai tujuannnya.

Disiplin kerja pegawai adalah perilaku seseorang yang sesuai dengan peraturan, prosedur kerja yang ada atau disiplin adalah sikap, tingkah laku dan perbuatan yang sesuai dengan peraturan dari organisasi baik tertulis maupun yang tidak tertulis.(Edy Sutrisno, 2016:89).

Menurut Maskoeri Jasin (2013) disiplin meliputi disiplin diri dan didisplin kelompok. Disiplin diri merupakan disiplin yang dikembangkan atau dikontrol oleh diri sendiri, yang merupakan manifestasi atau aktualisasi dari tanggung jawab pribadi, merupakan pengakuan dan penerimaan nilai-nilai yang ada di luar dirinya. Disiplin diri mencerminkan tanggung jawab dan kemampuan mengatur diri sendiri untuk kepentingan bersama. Melalui disiplin diri seorang karyawan selain menghargai dirinya sendiri juga menghargai orang lain. Sedangkan disiplin kelompok adalah merupakan bentuk penghargaan terhadap kelompok dengan mengikuti standar ukuran prestasi yang telah ditentukan. Disiplin kelompok akan tercapai jika disiplin diri telah tumbuh dalam diri karyawan. Kelompok akan menghasilkan pekerjaan yang optimal jika masingmasing anggota kelompok dapat memberikan andil yang sesuai dengan hak dan tanggungjawabnya.

Faktor-faktor dalam disiplin kerja meliputi faktor kepribadian dan faktor lingkungan. Faktor yang penting dalam kepribadian seseorang adalah system nilai yang dianut yang berkaitan dengan disiplin. Nilai-nilai menjunjung disiplin yang diajarkan atau ditanamkan orang tua, guru dan masyarakat akan digunakan sebagai kerangka acuan bagi penerapan disiplin di tempat kerja. Disiplin kerja yang tinggi tidak muncul begitu saja tetapi merupakan suatu proses belajar yang terus menerus. Disiplin kerja selain dipengaruhi faktor lingkungan kerja, juga dipengaruhi oleh kepribadian, maka ketidakhadiran salah satu faktor akan menyebabkan pelanggaran aturan. Jika salah satu karyawan melanggar maka perlu dilakukan upaya-upaya tindakan pendisiplinan agar prinsip-prinsip sosialisasi disiplin seperti adil dapat dipertahankan.

\section{Koordinasi}

Menurut Awaludin dalam Hasibuan (2011:86) koordinasi adalah suatu usaha kerja sama antara badan, instansi, unit dalam pelaksanaan tugas-tugas tertentu, sehingga terhadap saling mengisi, saling membantu dan saling melengkapi.

Menurut G.R. Terry (2010) koordinasi adalah upaya terutur dan sinkron dalam penyediaan jumlah dan waktu yang sesuai dan pengarahan kegiatan dalam rangka menciptakan suatu tindakan yang selaras dan harmonis tentang tujuan yang telah ditetapkan.

Menurut Siagian (2015) koordinasi adalah pengaturan keterkaitan pada usaha bersama dalam rangka mencapai keseragaman tindakan untuk meraih 
tujuan bersama. Koordinasi juga merupakan proses pengaturan supaya pembagian tugas setiap individu maupun grup mampu terbentuk sebagai kebutuhan yang terintegrasi dengan efisien.

Dalam Taliziduhu Ndraha (2003:295) tujuan koordinasi meliputi: 1) menciptakan dan memelihara efektivitas organisasi setinggi mungkin melalui sinkronisasi, penyerasian, kebersamaan, dan kesinambungan, antar berbagai dependen suatu organisasi, 2) mencegah konflik dan menciptakan efisiensi setinggi-tingginya setiap kegiatna interdependen yang berbeda-beda melalui kesepakatankesepakatan yang mengikat semua pihak yang bersangkutan, dan 3) menciptakan dan melelihara iklim dan sikap saling responsive-antisipatif di kalangan unit kerja interdependen yang berbeda-beda, agar keberhasilan unit kerja yang satu tidak rusha oleh keberhasilan unit kerja yang lain, melalui jaringan informasi dan komunikasi efektif.

Menurut Hasibuan (2012)) bentuk koordinasi meliputi koordinasi vertikal dan koordinasi horizontal. Koordinasi vertikal yaitu tindakan-tindakan atau kegiatan-kegiatan penyatuan, pengarahan, yang dijalankan oleh atasan terhadap kegiatan-kegiatan unit-unit, kesatuankesatuan kerja yang ada di bawah wewenang dan tanggung jawabnya. Koordinasi horizontal, yaitu tindakantindakan atau kegiatan-kegiatan penyatuan, pengarahan yang dijalankan terhadap kegiatan-kegiatan di dalam tingkat organisasi yang setingkat. Koordinasi horizontal terbagi atas dua yaitu: 1) Interdiciplinary, yaitu suatu koordainasi dalam rangka mengarahkan, menyatukan tindakan-tindakan, mewujudkan, menciptkan disiplin antara unit yang satu dengan unit yang lain secara intern maupun secara ekstern pada unitunit yang sama tugasnya dan 2) Inter- related, yaitu koordinasi antar badan (instansi), yaitu unit-unti yang fungsinya berbeda, tetapi instansi yang satu dengan yang lain saling bergantungan atau mempunyai kaitan baik secara intern maupun ekstern yang levelnya setaraf (Hasibuan, 2012).

\section{Kinerja}

Kinerja menurut Mangkunegara (2005) adalah hasil kerja secara kualitas dan kuantitas yang dicapai oleh seseorang pegawai dalam melaksanakan tugasnya sesuai dengan tanggung jawab yang diberikan kepadanya. Dijelaskan juga oleh Koesmono (2005) bahwa kinerja adalah prestasi karyawan dari tugas-tugas yang telah ditetapkan.

Hasibuan (2015) menyebutkan bahwa kinerja (prestasi kerja) sebagai hasil kerja secara kualitas dan kuantitas yang dicapai oleh seorang pegawai dalam melaksanakan tugasnya sesuai dengan tanggung jawab yang diberikan kepadanya. Faktor-faktor yang mempengaruhi kinerja adalah faktor kemampuan (ability) dan faktor motivasi (motivation). Faktor kemampuan (ability), secara psikologis, kemampuan terdiri dari kemampuan potensi (IQ) dan kemampuan reality (knowledge+skill).

Menurut Simamora dalam Prabu Mangkunegara (2013) kinerja dipengaruhi oleh tiga hal yaitu: faktor individual yang terdiri dari kemampuan dan keahlian, latar belakang dan demografi, faktor psikologis yang terdiri dari persepsi, attitude, personality, pembelajaran dan motivasi. Faktor organisasi terdiri dari sumberdaya, kepemimpinan, penghargaan, struktur dan job design.

Menurut Robbins (2007), kinerja merupakan wujud hasil kerja yang dihasilkan oleh seseorang. Kinerja digunakan sebagi dasar penilaian atau evaluasi dan sistem yang merupakan 
kekuatan penting untuk memengaruhi perilaku karyawan. Penilaian kinerja mempunyai tujuan untuk memotivasi para karyawan dalam mencapai sasaran organisasidan dalam mematuhi perilaku yang telah ditetapkan sebelumnya, agar membuahkan tindakan dan hasil yang diinginkan.

Pabundu Tika (2014) menyebutkan bahwa kinerja sebagai hasil-hasil fungsi pekerjaan/kegiatan seseorang atau kelompok dalam suatu kegiatan organisasi yang dipengaruhi oleh berbagai faktor untuk mencapai tujuan organisasi dalam periode tertentu. Fungsi kegiatan atua pekerjaan yang dimaksud disini ialah pelaksanaan hasil pekerjaan atau kegiatan seseorng atau kelompok yang menjadi wewenang dan tanggung jawabnya dalam suatu organisasi. Pelaksanaan hasil pekerjaan/prestasi kerja tersebut diarahkan untuk mencapai tujuan organisasi dalam jangka waktu tertentu.

Dessler (2015) menjelaskan bahwa penilaian kinerja merupakan upaya membandingkan prestasi aktual karyawan dan prestasi kerja yang diharapkan darinya. Dalam penilaian kinerja karyawan tidak hanya menilai secara fisik, tetapi pelaksanaan pekerjaan secara keseluruhan menyangkut berbagai bidang seperti kemampuan kerja, kerajinan, disiplin, hubungan kerja, atau hal-hal khusus sesuai dengan bidang dan tingkatan pekerjaan.

\section{Kerangka Pemikiran}

Dalam meningkatkan kinerja
karyawan, perusahaan harus
memperhatikan factor budaya kerja,
disiplin kerja dan koordinasi yang ada saat
ini. Budaya kerja merupakan factor yang
mempunyai kaitan dengan peningkatan
kinerja karyawan. Budaya kerja yang
sudah ada diupayakan untuk diubah
menjadi lebih baik sehingga mampu
memberikan peningkatan pada kinerja

karyawan. Disiplin kerja karyawan berperan dalam mempengaruhi kinerja karyawan. Disiplin kerja yang tinggi akan mempengaruhi tingkat kinerja karyawan.

Kerangka pemikiran penelitian dapat digambarkan sebagai berikut:

Gambar 1

Skema Kerangka Pemikiran

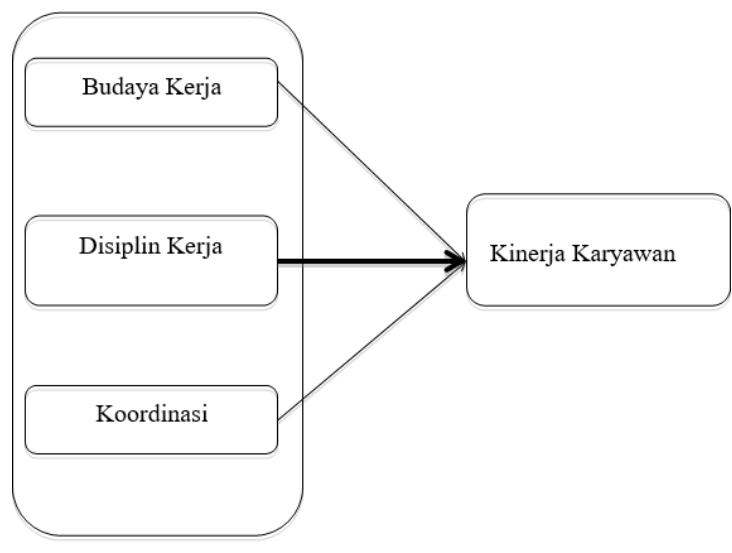

Sumber: Data diolah

\section{Hipotesis}

Hipotesis pada penelitian ini adalah:

H1 : Ada pengaruh budaya kerja terhadap kinerja karyawan PT Kereta Api Indonesia (Persero) Daop 1 Jakarta.

H2 : Ada pengaruh disiplin kerja terhadap kinerja karyawan PT Kereta Api Indonesia (Persero) Daop 1 Jakarta.

H3 : Ada pengaruh koordinasi terhadap kinerja karyawan PT Kereta Api Indonesia (Persero) Daop 1 Jakarta.

H4 : Ada pengaruh budaya kerja, disiplin kerja dan koordinasi secara simultan terhadap kinerja karyawan PT Kereta Api Indonesia (Persero) Daop 1 Jakarta.

\section{METODE PENELITIAN \\ Tempat dan Waktu Penelitian}

Penelitian ini mengambil objek penelitian pada PT Kereta Api Indonesia 
(Persero) Daop 1 Jakarta, yang berlokasi di Jalan Pegangsaan Timur No.15-16 Menteng Kota Jakarta Pusat.

Waktu yang digunakan peneliti untuk penelitian ini sejak tanggal dikeluarkannya Surat Edaran Penelitian dalam kurun waktu 3 (tiga) bulan, 1 bulan pengumpulan data, 1 bulan pengolahan data dan 1 bulan untuk pembahasan dan penyempurnaan penelitian.

\section{Definisi Operasional}

Definisi untuk masing-masing variabel adalah sebagai berikut:

- Budaya kerja merupakan sistem nilai, persepsi, perilaku dan keyakinan yang dianut oleh tiap individu karyawan dan kelompok karyawan tentang makna kerja dan refleksinya dalam kegiatan mencapai tujuan organsiasi dan individual. Budaya kerja adalah kondisi dan iklim kerja yang diciptakan oleh pimpinan dan diberlakukan dalam organisasi untuk dijadikan pedoman sikap dan perilaku pegawai dalam melaksanakan tugas.

- Disiplin kerja yakni kesadaran dan kesediaan seseorang menaati semua peraturan perusahaan dan normanorma sosial yang berlaku. Dengan disiplin kerja yang baik pada diri karyawan, maka akan semakin tinggi prestasi kerja yang akan dicapainya.

- Koordinasi adalah proses mensinergikan dan menyeimbangkan segala aktivitas dalam pekerjaan antara satu pihak dengan pihak lainnya untuk meraih tujuan tiap-tiap pihak sekaligus tujuan bersama. G.R. Terry berpendapat bahwa, koordinasi merupakan suatu usaha yang sinkron dan teratur untuk menyediakan jumlah dan waktu yang tepat, dan mengarahkan pelaksanaan untuk menghasilkan suatu tindakan yang seragam dan harmonis pada sasaran yang telah ditentukan.

- Kinerja (prestasi kerja) sebagai hasil kerja secara kualitas dan kuantitas yang dicapai oleh seorang pegawai dalam melaksanakan tugasnya sesuai dengan tanggung jawab yang diberikan kepadanya. Faktor-faktor yang mempengaruhi kinerja adalah faktor kemampuan (ability) dan faktor motivasi (motivation).

\section{Indikator Variabel Penelitian}

Adapun indikator dari masing-masing variabel sebagai berikut:

Tabel 1

Operasionalisasi Instrumen Penelitian

\begin{tabular}{|c|c|c|}
\hline Variabel & Indikator & Skala \\
\hline $\begin{array}{l}\mathrm{X}_{1}: \\
\text { Budaya Kerja }\end{array}$ & \begin{tabular}{|ll} 
1. & Nilai \\
2. & Kebiasaan \\
3. & Sikap \\
4. & Perilaku \\
5. & Pedoman
\end{tabular} & Likert \\
\hline $\begin{array}{l}\mathrm{X}_{2} \text { : Disiplin } \\
\text { Kerja }\end{array}$ & $\begin{array}{ll}\text { 1. } & \text { Kesadaran } \\
\text { 2. } & \text { Kesediaan } \\
\text { 3. } & \text { Ketaatan } \\
\text { 4. } & \text { Kepatuhan } \\
\text { 5. } & \text { komitmen }\end{array}$ & Likert \\
\hline $\mathrm{X}_{3}$ : Koordinasi & $\begin{array}{ll}\text { 1. } & \text { Sinergi } \\
\text { 2. } & \text { Keseimbangan } \\
\text { 3. } & \text { Keteraturan } \\
\text { 4. } & \text { Pengarahan } \\
\text { 5. } & \text { Penyatuan } \\
\end{array}$ & Likert \\
\hline Y: Kinerja & $\begin{array}{ll}\text { 1. } & \text { Hasil Kerja } \\
\text { 2. } & \text { Kemampuan } \\
\text { 3. } & \text { Kualitas } \\
\text { 4. } & \text { Kreativitas } \\
\text { 5. } & \text { Kuantitas } \\
\end{array}$ & Likert \\
\hline
\end{tabular}

Sumber: Kajian Literatur

\section{Populasi dan Sampel \\ Populasi}

Sujarweni dan Endrayanto (2012:13) mengatakan bahwa, populasi adalah wilayah generalisasi yang terdiri atas 
objek/subjek yang mempunyai kualitas dan karakteristik tertentu yang ditetapkan oleh peneliti untuk dipelajari dan kemudian ditarik kesimpulannya. Populasi adalah totalitas dari semua objek atau individu yang memiliki karakteristik tertentu, jelas dan lengkap yang akan diteliti. Populasi dalam penelitian ini adalah seluruh pegawai di PT Kereta Api Indonesia (Persero) Daop 1 Jakarta Pusat, yaitu sebanyak 70 orang.

\section{Sampel}

Menurut Sugiyono (2011) sampel adalah bagian dari jumlah dan karakteristik yang dimiliki oleh populasi. Penentuan jumlah sampel dapat dilakukan cara perhitungan statistic yaitu dengan menggunakan Rumusl Slovin. Rumus tersebut digunakan untuk menentukan ukuran sampel dari populasi yang telah diketahui jumlahnya yaitu sebanyak 178 orang. Untuk tingkat presisi yang ditetapkan adalah $10 \%$.

Jumlah populasi dalam penelitian ini adalah 70 orang, sehingga persentase kelonggaran yang digunakan adalah $10 \%$. Hasil perhitungan menghasilkan sampel sebesar 40 responden.

\section{Teknik Pengumpulan Data}

Teknik pengumpulan data adalah ketepatan cara-cara yang digunakan oleh peneliti untuk mengumpulkan data. Dalam pengumpulan data ini, peneliti menggunakan metode sebagai berikut:

1. Metode Observasi

Metode observasi yaitu pengamatan dan pencatatan secara sistematik terhadap gejala yang tampak pada objek penelitian. Observasi ini merupakan metode pengumpulan data yang menggunakan pengamatan terhadap obyek penelitian yang dapat dilaksanakan secara langsung maupun tidak langsung.
2. Metode Kuesioner

Metode kuesioner adalah suatu daftar berisikan rangkaian pertanyaan mengenai sesuatu masalah atau bidang yang akan diteliti. Untuk memperoleh data, kuesioner disebarkan kepada para responden terutama pada penelitian survei.

\section{Uji Validitas dan Reliablitas Instrumen}

- Uji Validitas

Uji ini untuk mengukur apakah data yang telah didapat setelah penelitian merupakan data yang valid dengan alat ukur yang telah disediakan (kuisioner), pengujian validitas dilakukan dengan membagikan kuesioner kepada 40 responden, dimana kuesioner berisi pertanyaan yang harus dijawab oleh para responden. Pertanyaan uji validitas dan reliabilitas kuesioner dalam penelitian ini menggunakan software SPSS (Statistic Product and Social Science) versi 16.0. Pengujian konstruk validitas data melalui analisis faktor dengan mengkorelasikan jumlah skor faktor dengan skor total. Bila korelasi tiap faktor tersebut positif dan besarnya 0,3 ke atas maka instrumen tersebut memiliki validitas yang baik.

- Uji Reliabilitas

Uji ini untuk melihat apakah alat ukur yang digunakan (kuesioner) menunjukkan konsistensi di dalam mengukur gejala yang sama. Uji Reliabilitas digunakan untuk mengetahui konsistensi atau kepercayaan hasil ukur yang mengandung kecermatan pengukuran. Instrumen yang reliabel adalah instrumen yang apabila digunakan beberapa kali untuk mengukur obyek yang sama akan menghasilkan data yang sama. Dalam perhitungan SPSS untuk menentukan 
nilai reliabilitas data adalah dari nilai Cronbach's Alpha. Menurut Nunnaly (2002) suatu "construct" dianggap reliabel jika koefisien alphanya $>0,60$.

\section{Metode Analisis Data Uji Asumsi Klasik}

\section{- Uji Normalitas}

Dilakukan untuk memastikan bahwa data variabel penelitian berasal dari data yang berdistribusi normal. Pada uji ini digunakan grafik normal PP Plot hasil pengolahan dengan program SPSS. Asumsi normalitas adalah jika titik-titik data hasil regresi tersebar di seputar garis diagonal pada grafik normal PP Plot.

- Uji Multikolinearitas

Uji Multikolinearitas dilakukan dengan melihat nilai VIF dan tolerance hasil pengolahan dengan program SPSS. Hasil yang baik diperoleh jika nilai tolerance mendekati angka satu dan nilai VIF berada di seputar 1 dan maksimal 10.

- Uji Heteroskedastisitas

Salah satu syarat pengujian regresi adalah adanya hubungan linier antar variabel. Uji heteroskedastisitas dengan menggunakan grafis hasil uji SPSS dengan melihat Grafis Scatter Plot. Hasil uji dikatakan baik atau tidak adanya masalah linieritas apabila titik-titik hasil perhitungan relatif menyebar secara acak di atas dan di bawah titik origin serta tidak membentuk pola tertentu.

\section{Analisis Regresi Linier Berganda}

Analisis ini digunakan untuk mengetahui seberapa besar pengaruh variabel bebas yaitu: Budaya Kerja (X1), Disiplin Kerja (X2) dan Koordinasi (X3) terhadap variabel terikatnya yaitu Kinerja (Y). Persamaan regresi linier berganda adalah sebagai berikut (Ghozali, 2005):

$$
\mathrm{Y}=\mathrm{a}+\mathrm{b} 1 \mathrm{X} 1+\mathrm{b} 2 \mathrm{X} 2+\mathrm{b} 3 \mathrm{X} 3
$$

Dimana:

$\mathrm{Y}=$ Variabel dependen (kinerja)

$\mathrm{a}=$ Konstanta

b1, b2, b3 = Koefisien garis regresi

X1, X2, X3 = Variabel independen (Budaya

Kerja, Disiplin Kerja, Koordinasi)

\section{Uji Hipotesis}

Pengujian hipotesis dalam penelitian ini menggunakan:

a. Parsial Test

Partial test dilakukan untuk membandingkan nilai thitung dengan $\mathrm{t}$ tabel atau melihat $\mathrm{P}$ value masingmasing variabel, sehingga dapat ditentukan apakah hipotesis yang telah kita buat signifikan, dan lebih besar dari $t$ tabel atau $t$ value $<$ a maka koefisien regresi adalah signifikan, dan hipotesis alternatif penelitian diterima, artinya variabel independen yang bersangkutan tidak berpengaruh terhadap variabel independen. Sebaliknya jika $\mathrm{t}$ hitung $<\mathrm{t}$ tabel $>\mathrm{a}$, artinya variabel independen yang bersangkutan tidak berpengaruh terhadap variabel dependen.

b. Simultan Test

Uji $F$ digunakan untuk menguji kebenaran antara variabel-variabel independen terhadap variabel dependen yang terdapat dalam model regresi. Analisis uji F ini dilakukan dengan membandingkan antara $\mathrm{F}$ hitung dengan $F$ tabel. Sebelum membandingkan nilai $f$ tersebut, juga harus ditentukan tingkat kepercayaan 95\%. Jika $\mathrm{F}$ hitung $>\mathrm{F}$ tabel atau $\mathrm{P}$ value $>$ a, disebut tidak signifikan, sebaliknya jika $\mathrm{F}$ hitung $<\mathrm{F}$ tabel atau $\mathrm{P}$ value $>$ a disebut signifikan. Uji F dilakukan untuk melihat secara serentak apakah variabel independen mampu menjelaskan variabel dependen. 


\section{Koefisien Determinasi (R2)}

Koefisien determinasi (R2) adalah koefisien yang menunjukkan persentase pengaruh semua variabel independen terhadap variabel dependen. Persentase tersebut menunjukan seberapa besar variabel independen dapat menjelaskan variabel dependen. Untuk kenaikan pada setiap penambanan pada variabel, maka digunakan nilai Adjusted R2. Karena nilai Adjusted R2 dapat naik atau turun apabila satu variabel independen ditambahkan ke dalam model. Syarat koefisien determinasi dikatakan kuat atau lemah yaitu apabila (R2) mendekati angka 1, maka berarti variasi perubahan variabel bebas dapat menjelaskan variasi perubahan variabel bebas terhadap variabel terikat serentak adalah lemah (Ghozali:2005).

\section{HASIL PENELITIAN DAN PEMBAHASAN \\ Pengujian Validitas dan Reliabilitas Instrumen \\ Uji Validitas Instrumen}

Uji validitas menunjukan sejauh mana alat pengukur yang dipergunakan untuk mengukur apa yang diukur. Adapun caranya adalah dengan mengkorelasikan antara skor yang diperoleh pada masingmasing item pertanyaan dengan skor total individu. Pengujian validitas dilakukan dengan program SPSS dengan pengambilan keputusan berdasarkan nilai Corrected Item-Total Correlation $>0,3$, maka item/pertanyaan tersebut disebut valid dan sebaliknya.

Seluruh pertanyaan untuk variabel independen (Budaya Kerja, Disiplin Kerja dan Koordinasi) memiliki status valid, karena nilai Corrected Item-Total Correlation $>0,3$.

\section{Uji Reliabilitas Instrumen}

Uji Reliabilitas dilakukan terhadap item pertanyaan yang dinyatakan valid.
Suatu variabel dikatakan reliabel atau handal jika jawaban tehradap pertanyaan selalu konsisten. Koefisien reliabilitas instrumen dimaksudkan untuk melihat konsistensi jawaban butir-butir pertanyaan yang diberikan. Uji reliabilitas menggunakan rumus "Cronbach Alpha". Perhitungan menggunakan program SPSS, dan hasil yang diperoleh menunjukan bahwa nilai Cronbach Alpha untuk variabel independen (Budaya Kerja, Disiplin Kerja dan Koordinasi) >0,60, artinya ketiga variabel independen dinyatakan reliabel atau memenuhi persayaratan.

\section{Uji Asumsi Klasik \\ Uji Normalitas}

Uji normalitas berguna untuk menguji apakah dalam model regresi, variabel dependen dan variabelk independen memiliki distribusi normal atau tidak. Uji normalitas pada penelitian ini menggunakan distribusi pada grafik P-P plot. Berikut hasil uji normalitas dengan program SPSS:

Gambar 1

Uji Normalitas

Normal P.P Plot of Regression Standardized Residual

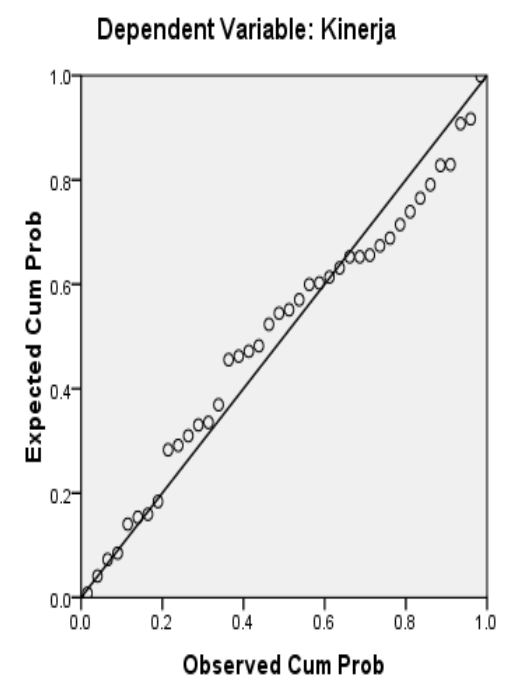




\section{Uji Multikoliniearitas}

Uji multikolinieritas digunakan untuk menguji apakah model regresi ditemukan adanya korelasi antar variabel independen. Untuk mengetahui ada tidaknya penyimpangan uji multikolinieritas adalah dengan melihat nilai Tolerance dan Variace Inflation Factor (VIF) masing-masing variabel independen. jika nilai Tolerance $>0,10$ dan nilai $\mathrm{VIF}<10$, maka data bebas dari gejala multikolinieritas. Hasil pengujian dapat diketahui sebagai berikut:

Tabel 2

Nilai VIF

\begin{tabular}{|ll|r|c|}
\hline \multirow{2}{*}{ Model } & \multicolumn{2}{|c|}{ Collinearity Statistics } \\
\cline { 3 - 4 } & Tolerance & \multicolumn{1}{c|}{ VIF } \\
\hline $1 \quad$ Constant) & & \\
& Budaya Kerja & .469 & 2.131 \\
& Disiplin kerja & .146 & 6.854 \\
& Koordinasi & .161 & 6.199 \\
\hline
\end{tabular}

Sumber: SPSS

Pada tabel di atas dapat diketahui bahwa nilai Tolerance masing-masing variabel indenpenden adalah sebesar 0,469, 0,146 dan $0,161>10 \%$ dan Variance Inflation Factor (VIF) untuk masingmasing variabel independen $=2,131,6,854$ dan $6,199<\mathrm{VIF}=10$, maka dapat disimpulkan bahwa antara variabel independen tidak terjadi multikolinieritas.

\section{Uji Heteroskedastisitas}

Uji Heteroskedastisitas bertujuan untuk menguji apakah dalam model regresi terjadi ketidaksamaan varians dari residual satu pengamatan ke pengamatan yang lain. Untuk mengetahui terjadi heteroskedastisitas atau tidak adalah dengan melihat Grafik Plot antara nilai prediksi variabel dependen yaitu ZPRED dengan residual SRESID. Dinyatakan tidak terjadi heteroskedastisitas apabila tidak pada pola yang jelas, serta titik-titik menyebar di atas dan di bawah angka 0 pada sumbu $Y$.

Hasil pengujiannya, sebagai berikut:

Gambar 2

Uji Heteroskedastisitas

Scatterplot

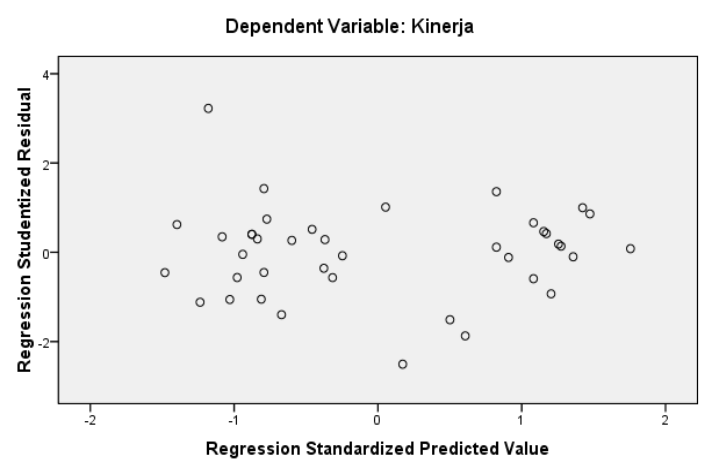

Sumber: SPSS

Pada gambar 2 di atas, terlihat bahwa tidak ada pola yang jelas dan titik-titik menyebar di bawah serta di atas sumbu Y. Hal ini menunjukkan bahwa variabel independen tidak terjadi heteroskedastisitas.

\section{Regresi Linier Berganda}

Analisis Regresi Linear Berganda digunakan untuk mengukur pengaruh antara lebih dari satu variabel prediktor (variabel bebas) terhadap variabel terikat.

Hasil pengujian yang dilakukan dapat dilihat pada tabel berikut:

Tabel 3

Regresi Linier Berganda

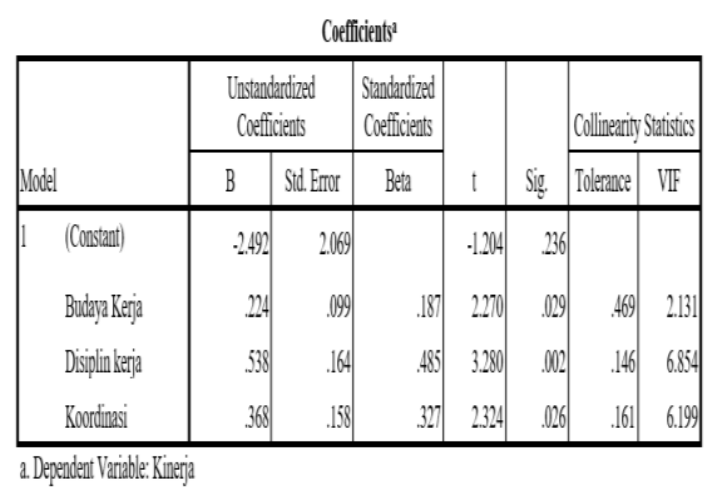

Sumber: data diolah SPSS 
Tabel di atas menunjukkan model persamaan regresi linier ganda yang dibentuk berdasarkan hasil perhitungan adalah:

$$
\hat{Y}=-2,492+0,224 X 1+0,538 X 2+0,368 X 3 \text {. }
$$

Sedangkan arti dari persamaan di atas adalah:

- Nilai konstanta a $=-2,492$, artinya jika tidak ada pengaruh budaya kerja, disiplin kerja dan koordinasi, maka nilai Kinerja sebeser -2,492.

- $\quad$ Budaya kerja b1 $=0,224$ memiliki nilai probabilitas Sig $=0,029$ atau Sig< $<$ $(0,029<0,05)$, maka nilai koefisien regresi budaya kerja dikatakan signifikan dan dapat diinterpretasikan yaitu jika budaya kerja meningkat satu satuan maka kinerja pegawai meningkat yaitu sebesar 0,224 satuan dengan asumsi disiplin kerja dan koordinasi konstan.

- $\quad$ Nilai koefisien regresi disiplin kerja b2 $=0,538$ memiliki nilai probabilitas Sig $=0,002$ atau Sig <a $(0,02<0,05)$, maka nilai koefisien regresi disiplin kerja dikatakan signifikan dan dapat diinterpretasikan yaitu jika disiplin kerja meningkat satu satuan maka kinerja pegawai meningkat yaitu sebesar 0,538 satuan dengan asumsi budaya kerja dan koordinasi konstan.

- $\quad$ Nilai koefisien regresi koordinasi b3 = 0,368 memiliki nilai probabilitas Sig $=$ 0,026 atau Sig<a $(0,026<0,05)$, maka nilai koefisien regresi koordinasi dikatakan signifikan dan dapat diinterpretasikan yaitu jika koordinasi meningkat satu satuan maka kinerja pegawai meningkat yaitu sebesar 0,368 satuan dengan asumsi budaya kerja dan disiplin kerja konstan.

\section{Koefisien Determinasi}

R2 atau koefisien determinasi (R2) ini mencerminkan seberapa besar variasi dari variabel terikat $\mathrm{Y}$ dapat diterangkan oleh variabel bebas $X$. Bila nilai koefisien determinasi sama dengan $0(\mathrm{R} 2=0)$, artinya variasi dari $\mathrm{Y}$ tidak dapat diterangkan oleh $X$ sama sekali. Sementara bila $\mathrm{R} 2=1$, artinya variasi dari $\mathrm{Y}$ secara keseluruhan dapat diterangkan oleh $X$. Dengan kata lain bila $\mathrm{R} 2=1$, maka semua titik pengamatan berada tepat pada garis regresi.

Menurut Santoso (Priyatno, 2008:81), Adjusted R square adalah $\mathrm{R}$ square yang telah disesuaikan nilai ini selalu lebih kecil dari R square dari angka ini bisa memiliki harga negatif, bahwa untuk regresi dengan lebih dari dua variabel bebas digunakan Adjusted R2 sebagai koefisien determinasi. Dari hasil pengujian yang dilakukan sebagai berikut:

\section{Tabel 4}

Model Summary Iodel Summarry

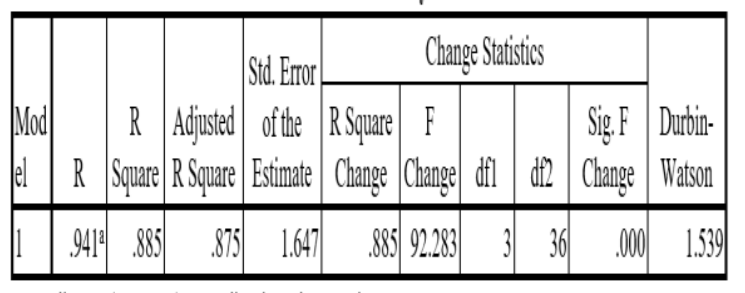

a. Predictors: (Constant), Koordinasi, Budaya Kerja,

Disiplin kerja

\section{Dependent Variable: Kinerja}

Sumber: data diolah SPSS

Tabel di atas menunjukkan bahwa nilai koefisien korelasi ganda $\mathrm{R}=0,941$ dan koefisien determinasi ganda yang disesuaikan atau Adjusted $\mathrm{R}$ Square $=0,875$ atau $87,5 \%$ sehingga dapat diinterpretasikan bahwa budaya kerja, disiplin kerja dan koordinasi secara bersama-sama mempengaruhi kinerja sebesar $87,5 \%$ sedangkan $12 \%$ sisanya dipengaruhi oleh variabel lain.

\section{Uji Hipotesis \\ Uji $t$}

Uji $t$ menunjukkan seberapa jauh pengaruh variabel independen secara 
individual dalam menerangkan variasi variabel dependen. Uji $t$ dalam penelitian ini dilakukan dengan membandingkan signifikansi $\mathrm{t}$ dengan a sebesar 0,05 atau $5 \%$.

Pengujian yang dilakukan adalah sebagai berikut:

a. Bila nilai signifikansi $t$ untuk Budaya Kerja, Disiplin Kerja dan Koordinasi >

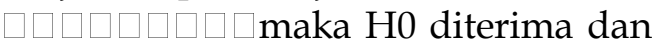
Ha ditolak.

b. Bila nilai signifikansi $\mathrm{t}$ untuk Budaya Kerja, Disiplin Kerja dan Koordinasi <

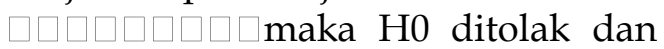
Ha diterima.

Hasil uji $t$ juga dilihat dari tabel "Coefficient", berikut ini:

Tabel 5

Coefficients

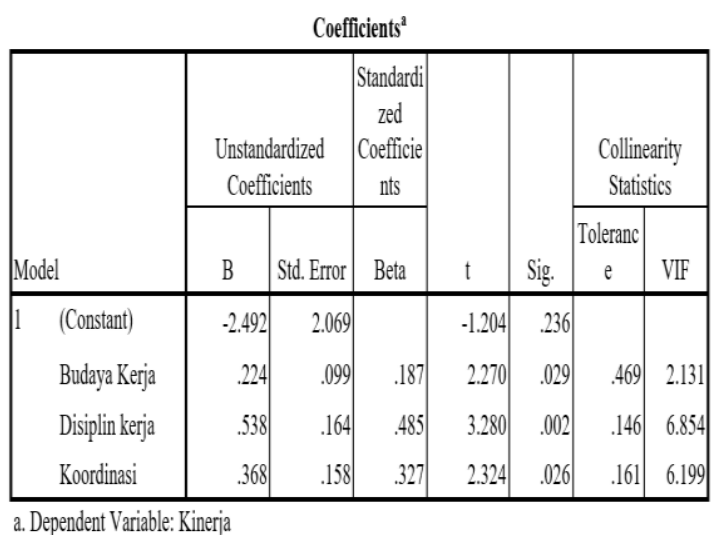

Sumber: data diolah SPSS

Tabel di atas menjelaskan bahwa:

a. Budaya Kerja memiliki nilai $t$ hitung 2,270 dengan nilai probabilitas signifikansi sebesar 0,029. Signfikansi t $<0,05$, maka Ha diterima yang berarti terdapat pengaruh signfikan antara Budaya Kerja terhadap Kinerja.

b. Disiplin Kerja memiliki nilai $t$ hitung 3,280 dengan nilai probabilitas signifikansi sebesar 0,002. Signfikansi t $<0,05$, maka Ha diterima yang berarti terdapat pengaruh signfikan antara Disiplin Kerja terhadap Kinerja. c. Koordinasi memiliki nilai $\mathrm{t}$ hitung 2,324 dengan nilai probabilitas signifikansi sebesar 0,026. Signfikansi t $<0,05$, maka Ha diterima yang berarti terdapat pengaruh signfikan antara Koordinasi terhadap Kinerja.

\section{Uji F}

Uji $\mathrm{F}$ digunakan untuk mengetahui apakah variabel-variabel independen secara simultan berpengaruh signifikan terhadap variabel dependen. Taraf signifikan $\alpha=0,05$ Derajat kepercayaan yang digunakan adalah 0,05 . Apabila nilai $F$ hasil perhitungan lebih besar daripada nilai $F$ menurut tabel maka hipotesis alternatif, yang menyatakan bahwa semua variabel independen secara simultan berpengaruh signifikan terhadap variabel dependen.

Kriteria pengujian dimana $\mathrm{Ha}$ diterima apabila $\mathrm{p}$ value $<\mathrm{a}$ dan Ha ditolak apabila $p$ value $>a$. Untuk analisisnya dapat dilihat dari tabel "Anova", berikut:

Tabel 6

ANOVA

\begin{tabular}{|c|c|c|c|c|c|}
\hline \multicolumn{6}{|c|}{$\mathrm{ANOVA}^{\mathrm{b}}$} \\
\hline Model & Sum of Squares & $\mathrm{df}$ & Mean Square & $\mathrm{F}$ & Sig. \\
\hline Regression & 750.773 & & 250.258 & 92.283 & $.000^{\circ}$ \\
\hline Residual & 97.627 & 3 & 2.712 & & \\
\hline Total & 848.400 & 3 & & & \\
\hline
\end{tabular}

a. Predictors: (Constant), Koordinasi, Budaya Kerja, Disiplin kerja

b. Dependent Variable: Kinerja

\section{Sumber: SPSS}

Tabel di atas menunjukan nilai Fhitung sebesar 92,283 dengan nilai probabilitas $(\operatorname{sig})=0,000$. Nilai sig. lebih kecil dari nilai probabilitas 0,05 atau nilai 0,000<0,05; maka Ha diterima, berarti budaya kerja, disiplin kerja dan koordinasi secara bersama-sama (simultan) berpengaruh signifikan terhadap kinerja karyawan PT Kereta Api Indonesia (Persero) Daop 1 Jakarta. 


\section{Pembahasan}

Hasil penelitian memberikan bukti bahwa budaya kerja secara parsial mempunyai pengaruh signifikan terhadap kinerja. Semakin tinggi budaya kerja maka semakin tinggi pula kinerja karyawan. Pengaruh budaya kerja terhadap kinerja adalah sebesar 0,224 dengan nilai sig sebesar 0,029<0,05. Bila ada peningkatan pada budaya kerja sebesar 1 (satu) satuan maka nilai kinerja menjadi sebesar 0,224 tetapi bila budaya kerja $=0$ atau tidak ada maka nilai kinerja adalah konstan sebesar 2,492 .

Hasil penelitian memberikan bukti bahwa disiplin kerja secara parsial mempunyai pengaruh signifikan terhadap kinerja. Semakin tinggi disiplin kerja maka semakin tinggi pula kinerja karyawan. Pengaruh disiplin kerja terhadap kinerja adalah sebesar 0,538 dengan nilai sig sebesar $0,002<0,05$. Bila ada peningkatan pada disiplin kerja sebesar 1 (satu) satuan maka nilai kinerja menjadi sebesar 0,538 tetapi bila disiplin kerja $=0$ atau tidak ada maka nilai kinerja adalah konstan sebesar 2,492 .

Hasil penelitian memberikan bukti bahwa koordinasi secara parsial mempunyai pengaruh signifikan terhadap kinerja. Semakin tinggi koordinasi maka semakin tinggi pula kinerja karyawan. Pengaruh koordinasi terhadap kinerja adalah sebesar 0,368 dengan nilai sig sebesar 0,026<0,05. Bila ada peningkatan pada koordinasi sebesar 1 (satu) satuan maka nilai kinerja menjadi sebesar 0,368 tetapi bila koordinasi $=0$ atau tidak ada maka nilai kinerja adalah konstan sebesar 2,492 .

Secara simultan budaya kerja, disiplin kerja dan kooordinasi mempunyai pengaruh yang signifikan terhadap kinerja karyawan. Hal ini dapat dibuktikan dari nilai Adjusted R Square sebesar 0,875 atau $87,5 \%$. Artinya pengaruh budaya kerja, disiplin kerja dan koordinasi secara simultan terhadap kinerja adalah sebesar $87,5 \%$ sedangkan sisanya sebesar $12 \%$ dipengaruhi faktor lain. Pada uji $F$ menunjukkan bahwa nilai $\mathrm{F}$ hitung $>\mathrm{F}$ tabel dan nilai sig sebesar 0,000<0,05 sehingga dapat diartikan bahwa pengaruh simultan antara budaya kerja, disiplin kerja dan koordinasi terbukti signifikan.

\section{KESIMPULAN}

Kesimpulan dari penelitian ini adalah sebagai berikut:

a. Budaya kerja terbukti mempunyai pengaruh positif dan signifikan terhadap kinerja karyawan. Budaya kerja pada PT Kereta Api Indonesia (Persero) Daop 1 Jakarta tergolong cukup tinggi, artinya penerapan budaya kerja sudah cukup efektif dan mampu meningkatkan komitmen serta konsistensi perilaku mereka terhadap perusahaan.

b. Disiplin kerja terbukti mempunyai pengaruh positif dan signifikan terhadap kinerja karyawan PT Kereta Api Indonesia (Persero) Daop 1 Jakarta. Dengan disiplin kerja yang tinggi dari para karyawan terutama disiplin diri dan disiplin kelompok, akan berpengaruh terhadap peningkatan kinerja di masa mendatang.

c. Koordinasi terbukti mempunyai pengaruh positif dan signifikan terhadap kinerja karyawan PT Kereta Api Indonesia (Persero) Daop 1 Jakarta, artinya bila koordinasi karyawan meningkat maka kinerja karyawan juga akan meningkat. Koordinasi dil lingkungan perusahaan tergolong cukup baik dan mampu membantu kelancaran kerja.

d. Budaya kerja, disiplin kerja dan koordinasi secara simultan (bersamasama) mempunyai pengaruh yang 
signifikan terhadap kinerja karyawan PT Kereta Api Indonesia (Persero) Daop 1 Jakarta dengan nilai Adjusted R Square sebesar $87,5 \%$ dan $12 \%$-nya dari faktor lain yang tidak masuk dalam penelitian. Peningkatan yang diprioritaskan adalah disiplin kerja karyawan kemudian koordinasi dan selanjutnya budaya kerja karyawan.

\section{SARAN}

Dari penelitian yang dilakukan, maka penulis menyarankan:

a. PT Kereta Api Indonesia (Persero) Daop 1 Jakarta perlu menjaga dan meningkatkan budaya kerja menjadi lebih baik untuk menciptakan kinerja yang optimal, terutama peningkatan semangat kerja, disiplin dan sikap santun serta hormat.

b. Disiplin kerja karyawan perlu lebih ditingkatkan lagi agar semakin kuat mempengaruhi kinerja karyawan. Upaya yang harus dilakukan adalah dengan memberikan pembinaan disiplin kepada para karyawan, khususnya dalam hal ketaatan, kepatuhan dan kesediaan bekerja sesuai dengan waktu yang telah ditetapkan.

c. Koordinasi yang ada saat ini tergolong cukup baik dan harus ditingkatkan. Koordinasi yang baik baik secara vertikal maupun horisontal akan berpengaruh terhadap kelancaran komunikasi dalam bekerja. Dengan koordinasi diharapkan keharmonisan atau keserasian seluruh kegiatan untuk mencapai tujuan yang diharapkan. Sehingga perusahaan atau bagian menjadi seimbang dan selaras.

d. Kinerja karyawan PT Kereta Api Indonesia (Persero) Daop 1 Jakarta tergolong cukup tinggi. Ke depannya penilaian kinerja harus tetap dilakukan untuk mengukur pencapaian kerja atau target kerja serta kemampuan dalam menyelesaikan pekerjaan, juga sikap kerjasama karyawan dalam menyelesaikan pekerjaan.

\section{DAFTAR PUSTAKA}

Ahyari, Agus. (2008). Manajemen Sumber Daya Manusia, Cetakan Pertama, Jakarta: Penerbit CV. Mas Agung

Budiharjo, Andreas. (2011). Organisasi: Menuju Pencapaian Kinerja Optimum. Jakarta: Prasetya Mulya Publishing

Chris Rowley dan Keith Jackson. (2012). Manajemen Sumber Daya Manusia. Jakarta: PT. RajaGrafindo Persada, Jakarta.

Dessler, Gary. (2015). Manajemen Sumber Daya Manusia. Edisi 14. Jakarta: Salemba Empat

Frances Hasselbein, et.al. (2003). On High Performance Organization. Jakarta: Elexmedia Komputindo

Ghozali, Imam. (2011). Aplikasi Analisis Multivariate dengan Program IMB SPSS 32 Update PLS Regresi. Semarang: Badan Peneliti Undip

Gudono. (2012). Teori Organisasi. Yogyakarta: BPFE

Handoko T Hani. (2010). Manajemen Personalia dan Sumber Daya Manusia. Yogyakarta: BPFE

Hasibuan. Malayu SP. (2012). Manajemen Sumber Daya Manusia, Jakarta: Bumi Aksara Ivancevich, John. M, dkk. (2008). Perilaku dan Manajemen Organisasi. Jakarta: Erlangga Jasin, A. (1989). Peningkatan Pembinaan Disiplin Nasional dalam Sistem dan Pola Pendidikan Nasional. Dalam 
Analisis CSIS. No. 4 Tahun XVII, JuliAgustus 1989. Jakarta: Centre for

Nawawi, Hadari. (2006). Evaluasi dan Manajemen Kinerja di Lingkungan Perusahaan dan Industri, Yogyakarta,: Gadjah Mada University Press

Ndraha, Taliziduhu. (2003). Kybernology 1: Ilmu Pemerintahan baru. Jakarta: Rineka Cipta

Nitisemito, Alex S. (2012). Manajemen Personalia, Cetakan ke-6 Penerbit Ghalia

Notoatmodjo, Soekidjo. (2009). Pengembangan Sumber Daya Manusia. Jakarta: Rineka Cipta

Priansa, Donni Junni. (2014). Perencanaan dan Pengembangan Sumber Daya Manusia, Bandung: Alfabeta

Richard L. Daft. (2010). Era Baru Manajemen. Buku 1 dan 2. Jakarta: Salemba Empat

Richardo, J. (2015). Pengaruh Pelatihan Kerja dan Motivasi Kerja terhadap Kinerja Karyawan PT. Prudential Cabang. Mrt Stars. Agora Vol.3 No. 2

Rivai, Veithzal dan Sagala J Ella. (2014). Manajemen Sumber Daya Manusia untuk Perusahaan dari Teori ke Praktik. Jakarta: PT Rajawali Pers
Rivai, Veithzal. (2004). Manajemen Sumber Daya Manusia Untuk Perusahaan: Dari Teori ke Praktik. Jakarta: PT. Raja Grafindo Persada.

Robbbins dan Judge. (2007). Perilaku Organisasi, Buku 1 dan 2. Jakarta: Salemba Empat

Ruky, Ahmad. (2002). Sistem Manajemen Kinerja. Jakarta: Gramedia Pustaka Utama.

Samsudin, Sadili. (2005). Manajemen Sumber Daya Manusia. Bandung Pustaka Setia

Siagian, Sondang. (2008). Manajemen SDM. Cet 16. Jakarta: Bumi Aksara.

Simanjuntak, Payaman J. (2005). Manajemen dan Evaluasi Kerja. Jakarta. Lembaga Penerbit FEUI

Sopiah. (2008). Perilaku Organisasi. Yogyakarta: Andi

Sugiyono. (2013) Metode Penelitian Bisnis, Bandung: CV Alfabeta

Umar, Husein. (2005). Evaluasi Kinerja Perusahaan. Jakarta: Gramedia Pustaka Utama

Wirawan. (2007). Budaya dan Iklim Organisasi. Jakarta: Salemba Empat

Wirawan. (2009). Evaluasi Kinerja Sumber Daya Manusia: Teori Aplikasi dan Penelitian. Jakarta: Salemba Empat 